\title{
Organisasi Pembelajar dan Manajemen Pengetahuan
}

\author{
Soeharno $^{1} \&$ Anco $^{2}$ \\ ${ }^{1}$ Fakultas Ilmu Pendidikan Universitas Negeri Jakarta \\ email: soeharno.unj@gmail.com \\ ${ }^{2}$ Pascasarjana Universitas Negeri Jakarta \\ email: ancofarhama@gmail.com
}

\begin{abstract}
Abstrak
Pengelolaan lembaga kontemporer dihadapkan pada isu-isu global, tidak lagi pada isu-isu lokal, apalagi sektoral. Konservatisme dalam mengelola organisasi harus rela ditinggalkan kemudian beralih pada praktik berorganisasi yang lebih fleksibel. Tidak ada yang tidak berubah, melainkan perubahan itu sendiri. Slogan ini menjadi lonceng bagi organisasi untuk tidak berada pada posisi stagnan, tetapi harus terus bergerak mengikuti arus perubahan. Teknologi big bang telah merubah wajah dunia dalam hitungan yang sangat cepat, bahkan oleh lembaga-lembaga yang low respons, dianggap sebagai kejadian yang tidak terkirakan. Namun demikian, beberapa lembaga menganggap peristiwa tersebut sebagai sesuatu yang positif sehingga menjadi momentum untuk belajar, bahkan belajar secara berkelanjutan. Dibutuhkan pemimpin yang terbuka, memimpin proses pembelajaran organisasi, sehingga seluruh level organisasi mengalami pemerataan pengetahuan. Dengan demikian, organisasi memiliki kesiapan untuk menghadapi segala kondisi. Tidak hanya mengandalkan pemberian pengetahuan, tetapi juga menciptkan iklim yang mendorong seluruh anggota organsasi untuk terus-menerus mengembangkan pengetahuan dan melakukan inovasi. Organisasi akhirnya memiliki tumpukan pengetahuan sebagai bahan mentah yang dapat dikelola untuk menghasilkan pengetahuan baru. Secara internal, pengetahuan yang dimiliki organisasi akan membantu dalam mempertahankan eksistensi organisasi, meramalkan kejadian-kejadian di masa mendatang, menyiapkan langkah-langkah antisipatif.
\end{abstract}

Kata Kunci: Organisasi Pembelajar, Manajemen Pengetahuan 
Learning Orgnization and Knowledge Management

\author{
Soeharno $^{1}$ \& Anco ${ }^{2}$ \\ ${ }^{1}$ Fakultas Ilmu Pendidikan Universitas Negeri Jakarta \\ email: soeharno.unj@gmail.com \\ ${ }^{2}$ Pascasarjana Universitas Negeri Jakarta \\ email: ancofarhama@gmail.com
}

\begin{abstract}
Management of contemporary institutions is confronted with global issues, no longer on local issues, let alone sectoral. Conservatism in managing organizations must be willing to be abandoned then move on to more flexible organizational practices. Nothing does not change, but the change itself. This slogan becomes a bell for the organization not to be in a stagnant position, but must continue to move with the flow of change. Big bang technology has changed the face of the world in a very fast count, even by institutions that are low-response, considered an unexpected event. However, some institutions consider the event as something positive so that it becomes a momentum for learning, even learning on an ongoing basis. Open leaders are needed, leading the learning process of the organization, so that all levels of the organization experience the distribution of knowledge. Thus, the organization has a readiness to deal with all conditions. Not only relying on the provision of knowledge, but also creating a climate that encourages all members of the organization to continuously develop knowledge and innovate. The organization finally has a pile of knowledge as raw material that can be managed to produce new knowledge. Internally, the organization's knowledge will help maintain the organization's existence, predict future events, prepare anticipatory steps.
\end{abstract}

Keywords: Learning Organization, Knowledge Management 


\section{Pendahuluan}

Perubahan lingkungan mengharuskan berbagai organisasi melakukan pembenahan secara internal. Ledakan kemajuan teknologi informasi dan komunikasi semakin menambah kecepatan perubahan lingkungan, yang mana organisasi dituntut untuk dapat menyesuaikan diri dengan irama perubahan itu. Pengelolaan organisasi yang bersifat tradisional seharusnya sudah ditinggalkan menuju pengelolaan organisasi yang adaptif terhadap kemajuan zaman. Tidak hanya dalam konteks sekali pakai, tetapi juga didesain agar dapat dikembangkan dalam berbagai situasi ${ }^{1}$.

Respons atas situasi organisasi digantungkan pada pemimpin. Jika pemimpinan menunjukkan respon rendah, maka sulit dibayangkan hadirnya organisasi yang gesit dan responsif ${ }^{2}$. Sebaliknya, pemimpin yang menunjukkan respon tinggi akan melibatkan seluruh level organisasi untuk meningkatkan kesiapan menghadapi berbagai keadaan ${ }^{3}$. Berbagai informasi tentang perkembangan pesaing, teknologi terbaru, hingga capaian-capaian terbaru terdistribusikan ke seluruh lapisan organisasi. Harapannya adalah agar seluruh anggota organisasi memiliki kesamaan informasi, kesamaan pandangan, hingga melahirkan tanggung jawab bersama. Tantangan yang dihadapi akan menjadi cambuk untuk belajar, sehingga atmosfir organisasi dilingkupi oleh suasana belajar.

Kemampuan organisasi bertahan dalam waktu yang lama terletak pada kemampuan organisasi itu untuk terus belajar ${ }^{4}$. Dengan cara itu organisasi memeroleh pemahaman, mampu memetakan persoalan, dan merumuskan strategi pemecahan masalah. Organisasi semacam ini sangat menyadari bahwa jurus bertahan tidak dapat

1 Tjahjadi, B. (2011). Hubungan sistem manajemen risiko dengan ketidakpastian lingkungan dan strategi serta dampaknya terhadap kinerja organisasi. Jurnal Ekonomi dan Bisnis Airlangga (JEBA)| Journal of Economics and Business Airlangga, 21(2).

${ }^{2}$ Syahrul, S. (2017). Perencanaan Strategis dan Praktiknya di Perguruan Tinggi. Shautut Tarbiyah, 23(1), 142-159.

${ }^{3}$ Syahrul, S. (2016). Readines Frame: Analisis Kerangka Kesiapan dalam Transformasi Pendidikan Tinggi (Pengalaman Iain Kendari). Al-Ta'dib, 9(1), 162181.

${ }^{4}$ Raharso, S., \& Amalia, S. (2011). Tim dan organisasi pembelajar. Jurnal Administrasi Bisnis, 7(2). 
diterapkan dalam situasi yang penuh persaingan, sebaliknya inovasiinovasi harus terus dijalankan.

Tugas berikutnya adalah mengelola pengetahuan, yaitu kesiapan pemimpin dalam melakukan inovasi, strategi dan taktik untuk mempertahankan, menganalisis, mengorganisasi, dan membagikan pengetahuan dan pengalaman ${ }^{5}$. Kepemimpinan yang dibutuhkan dalam hal ini adalah kepemimpinan terbuka, pemimpin pembelajar, yang tidak membiarkan pengetahuan dan pengalaman hanya berada di pusaran elit organisasi, tetapi menyebar ke seluruh tingkat organisasi ${ }^{6}$.

\section{Metode}

Artikel ini merupakan hasil kajian literatur tentang organisasi pembelajar dan manajemen pengetahuan. Prosedur yang ditempuh dalam kajian ini adalah dengan melakukan penelusuran berbagai literatur terkait organisasi pembelajar dan manajemen pengetahuan. Selanjutnya dilakukan klasifikasi dan kategorisasi tema pada kedua variabel tersebut. Kemudian dilakukan pembahasan dengan melakukan elaborasi konsep, temuan penelitian, dan teori. Tahap terakhir adalah penarikan kesimpulan.

\section{Organisasi Pembelajar dan Manajemen Pengetahuan: Jalan Menuju Keunggulan}

Itu adalah fakta yang mapan bahwa dunia mengalami transisi dari basis produksi menuju ekonomi berbasis pengetahuan. Hasilnya, organisasi makin tergantung pada inovasi pengetahuan untuk menciptakan nilai bagi pelanggan mereka. Pertanyaan bagi banyak permimpin adalah bagaimana mengorganisir orang, system, dan proses kedalam organisasi untuk menghasilkan dan mengeksploitasi bentuk-bentuk pengetahuan baru. Di dalam bukunya, The Fifth Disipine, Peter Senge membuat kasus yang menarik keberlangsungan hidup organisasi berkait dengan kemampuannya untuk belajar dan beradaptasi. Dia menggambarkan organisasi pembelajar sejati sebagai sesuatu yang dapat membangun tidak hanya kapabilitas baru tetapi

\footnotetext{
${ }^{5}$ Munir, N. S. (2011). Penerapan Manajemen Pengetahuan di Perusahaan di Indonesia. PPM Manajemen.

${ }^{6}$ Syahrul, S. (2015). Kepemimpinan dan Inovasi Lembaga Pendidikan (Pengalaman Pondok Gontor VII Putra Sulawesi Tenggara). Al-Ta'dib, 8(1), 82-100.
} 
juga perubahan mindset yang fundamental. Untuk tetap kompetitif, organisasi harus berinovasi secara terus-menerus.

\section{Deskripsi Organisasi Pembelajar}

Dalam sebuah lingkungan yang stabil, perubahan lambat dan incremental, dan organisasi memiliki waktu untuk bereaksi dan masih menahan posisi kompetitif mereka. Akan tetapi, dalam perubahan lingkungan yang cepat, perubahan berkali-kali dan terputus-putus; dan bereaksi bukanlah pendekatan terbaik untuk tetap kompetitif. Tantangannya adalah pada organisasi yang terkena untuk mengatasi hambatan dan mengeksploitasi peluang yang menghasilkan percepatan dinamika industri. Untuk berhasil, organisasi harus menyajikan karakter yang adaptif dan pembelajar terus-menerus ${ }^{7}$.

Organisasi pembelajar adalah terampil dalam menciptakan, mendapatkan, dan mentransfer pengetahuan, memodifikasi perilaku untuk mencerminkan penglihatan dan pengetahuan baru ${ }^{8}$. Itu melalui pembelajaran yang mana pengetahuan diciptakan. Contoh metode pembelajaran organisasi yang efektif mencakup implementasi inovasi balik, proses inovasi stage-gate, team to team, dan person to person baton-passing. Pada umumnya para peneliti setuju bahwa mengelola pengetahuan secara efektif dapat memberikan keunggulan bersaing bagi organisasi secara berkelanjutan. Pemimpin, terutama pada posisi puncak, harus menciptakan kesempatan yang mendukung dan memelihara pembelajaran kolektif (juga dikenal sebagai pembelajaran organisasi), untuk itu melalui proses ini yang mana anggota memperoleh pengetahuan dan membangun kapabilitas yang inovatif untuk menciptakan nilai.

Pengetahuan Organisasi adalah pengetahuan eksplisit dan diam-diam yang individu miliki tentang produk, layanan, system, dan proses ${ }^{9}$. Pengetahuan formal atau eksplisit diekspresikan dalam system aturan dan dengan mudah dikomunikasi dan dibagikan. Itu sering dikodifikasikan dalam manual, database, dan system informasi.

7 Wardani, A. K. (2018). Dormansi Organisasi Di Era Globalisasi. Moderat: Jurnal Ilmiah Ilmu Pemerintahan, 4(3), 28-35.

${ }^{8}$ Ismail, D. H. (2017). Strategi Mewujudkan Suatu Organisasi Pembelajar. Jurnal Lentera Bisnis, 5(1), 9-30.

9 Manullang, M. (2013). Pengaruh Pengetahuan Organisasi, Motivasi Berprestasi, Pengambilan Keputusan, Dan Komitmen Organisasi Terhadap Kinerja Kepala Sekolah Studi Pada Smp Kota Medan (Doctoral dissertation, UNIMED). 
Pengetahuan informal atau diam-diam adalah sangat personal, sulit dikomunikasikan, sangat berakar dalam tindakan, dan sangat kontekstual sifatnya. Seperti pengetahuan eksplisit, seperti desain produk ataupun gambaran proses bisnis, pengetahuan diam-diam instink dan intuisi yang dimiliki para praktisi berpengalaman.

Pembelajaran organisasi melibatkan sumber-sumber internal dan eksternal. Secara eksternal, sebuah organisasi dapat belajar dari pelanggan, pemasok, pesaing, industri dan publikasi akademik, mitra bisnis, dan konsultan. Secara internal, organisasi dapat belajar dari karyawan mereka. Setiap karyawan, yang bekerja secara langsung dengan pelanggan, adalah sumber gagasan baru yang besar ${ }^{10}$.

\section{Budaya Organisasi Pembelajar VS Budaya Organisasi Tradisional}

Bagaimanapun juga, banyak organisasi hari ini beroperasi dalam lingkungan yang ditandai oleh perubahan terus-menerus, and pada beberapa -seperti perusahaan high-tech- level perubahan adalah terputus-putus. Perubahan terputus-putus terjadi ketika perubahan yang diharapkan atau diantisipasi tidak seperti saat ini atau masa lalu. Munculnya teknologi yang lebih murah dan lebih baik, pengenalan saingan baru atau produk dan layanan yang lebih baik, persaingan dari pesaing asing biaya rendah, dan pergeseran demografis merupakan ancaman utama terhadap keuntungan dan bahkan keberlangsungan hidup banyak organisasi ${ }^{11}$. Dalam kondisi stabil, lingkungan yang tak ada benturan, organisasi fokus pada pencapaian tujuan-tujuan yang telah ditetapkan melalui system komando yang sangat terstruktur dengan job khusus dan hirarki vertical yang kuat. Namun, mengingat realitas lingkugan terkini, bentuk organisasi tradisional ini digantikan oleh bentuk organisasi pembelajar ${ }^{12}$. Perbedaan sederhana antara

${ }^{10}$ Marlikan, M. (2013). Pengaruh Pembelajaran Organisasi dan Motivasi kerja terhadap Kinerja Karyawan Koperasi Syariah. Manajemen Bisnis, 1(1), 57-64.

11 Trang, D. S. (2013). Gaya kepemimpinan dan budaya organisasi pengaruhnya terhadap kinerja karyawan. Jurnal EMBA: Jurnal Riset Ekonomi, Manajemen, Bisnis Dan Akuntansi, 1(3).

${ }^{12}$ Lisdiantini, N. (2013). Pengaruh Budaya Organisasi dan Kepemimpinan Kewirausahaan terhadap Motivasi Karyawan dan Dampaknya pada Peningkatan Kinerja Organisasi (Studi Pada PT Industri Kereta Api/INKA Madiun). Widya Warta, 37(02). 
organisasi tradisional dan organisasi pembelajar adalah pada budaya. Lihat gambar 1 sebagai perbandingan dari dua tipe organisasi tersebut. Gambar 1. Organisasi Tradisional VS Organisasi Pembelajar ${ }^{13}$

\begin{tabular}{|c|c|}
\hline $\begin{array}{l}\text { Tradisional } \\
\text { Efisiensi) }\end{array}$ & $\begin{array}{l}\text { Learning } \\
\text { Pembelajaran) }\end{array}$ \\
\hline - Lingkungan stabil & - Lingkungan berubah \\
\hline - Struktur Vertikal & - Struktur horizontal \\
\hline $\begin{array}{l}\text { - Strategi dirumuskan dari } \\
\text { atas dan diturunkan }\end{array}$ & $\begin{array}{l}\text { - Strategi adalah upaya bersama } \\
\text { dalam organisasi dan dengan } \\
\text { perusahaan lainnya }\end{array}$ \\
\hline $\begin{array}{l}\text { - Pengambilan keputusan } \\
\text { terpusat }\end{array}$ & $\begin{array}{l}\text { - Pengambilan keputusan } \\
\text { terdesentralisasi }\end{array}$ \\
\hline $\begin{array}{l}\text { - Tugas-tugas dispesialisasi } \\
\text { dan didefinisikan secara } \\
\text { kaku }\end{array}$ & $\begin{array}{l}\text { - Adaptasi peran, fleksibel, dan } \\
\text { longgar }\end{array}$ \\
\hline $\begin{array}{l}\text { - Budaya kaku yang tidak } \\
\text { responsive terhadap } \\
\text { perubahan }\end{array}$ & $\begin{array}{l}\text { - Budaya adaptif yang } \\
\text { mendorong perubahan dan } \\
\text { perbaikan terus-menerus }\end{array}$ \\
\hline $\begin{array}{l}\text { - System komunikasi formal } \\
\text { yang terjalin ke hirarki } \\
\text { vertical dengan sejumlah } \\
\text { filter }\end{array}$ & $\begin{array}{l}\text { - Jaringan bebas kelompok dan } \\
\text { personal, pertukaran terbuka } \\
\text { tanpa filter }\end{array}$ \\
\hline
\end{tabular}

Kajian dari Achua menunjukkan bahwa organisasi tradisional memiliki karakteristik sebagai berikut:

1. Organisasi tradisional didasarkan pada model birokrasi yang menekankan struktur kendali dan komando, pengambilan keputusan terpusat, system sangat formal, tugas-tugas dispesialisasi dan kaku, budaya tertutup. Struktur vertikal ini efektif di bawah lingkungan yang stabil dimana kecepatan perubahan lambat atau inkremental terbaik.

2. Budaya organisasi tradisional berorientasi kepada individu, dan ganjaran pun individual. Kompetisi ditumbuhkan di antara individu-individu.

13 Achua, C. F., \& Lussier, R. N. (2013). Effective leadership. SouthWestern Cengage Learning 
3. Ada sebuah mindset bahwa ada sebuah "cara baik" melakukan sesuatu, dan hanya ketika cara itu diikuti akan menjadikan organisasi sukses. Elaborasi system pelaporan formal memungkinkan pemimpin memantau pelaksanaan pekerjaan secara tertutup. System formal ini adalah alat kuasa bagi pengendalian informasi adan sering digunakan sebagai filter dalam menentukan apa informasi yang pemimpin putuskan untuk diturunkan ke tingkat bawah karyawan.

4. Karena organisasi tradisional mendorong efisiensi, penyimpangan dari prosedur operasi standard disukai dan kesalahan dipandang sebagai gejala miskin kinerja. Meskipun, karyawan tidak mengambil kesempatan, kesalahan dan masalah yang disembunyikan ${ }^{14}$.

Sebaliknya organisasi pembelajar dicirikan oleh atribut sebagai berikut:

1. Dalam organisasi pembelajar, struktur vertical ditinggalkan untuk datar, struktur horizontal. Struktur horizontal merupakan seputar alur pekerjaan atau proses yang lebih dari spesialisasi fungsional. Organisasi pembelajar mengetahui bahwa proses kerja dan prosedur bermakna untuk memuaskan kebutuhan pelanggan lebih dari tujuan dalam diri mereka sendiri. Struktur fleksibel tepat dalam lingkungan bisnis yang berubah secara cepat hari ini, dalam tekanan kompetisi, inovasi teknologi, perubahan pasar global, dan mengembangkan kebutuhan pelanggan yang mensyaratkan adaptasi dan penyesuaian yang konstan.

2. Kerja tim sangat dihargai, dan system jaringan yang memudahkan komunikasi dan pertukaran di seluruh organisasi dan dengan sumber eksternal lainnya. Para peneliti yang tertarik dalam hubungan jaringan telah mengetahui dimensi pengetahuan dari jaringan dan link dengan keberhasilan kompetisi. Mereka mengusulkan bahwa jaringan yang diberikan perusahaan dengan akses kepada pengetahuan, sumber daya, pasar dan teknologi.

3. Untuk mendorong inovasi dan kreatifitas dalam menemukan tantangan baru, organisasi pembelajar mendesain tugas-tugas yang jauh lebih longgar, mengalir bebas, dan adaptif. Beberapa aturan dan prosedur ketat menentukan bagaimana sesuatu seharusnya

14 Achua, C. F., \& Lussier, R. N. (2013). Effective leadership. SouthWestern Cengage Learning. 
dilakukan. Istilah organik digunakan untuk menggambarkan tipe organisasi ini. Tanggung jawab dan kewenangan didesentrasisasikan kepada pekerja tingkat bawah, memberdayakan mereka untuk berpikir, eksperimen, mencipta, belajar, dan menyelesaikan persoalan pada tingkat mereka.

4. Organisasi pembelajar adalah proses multilevel, menyatukan individu-individu, kelompok dan tingkat analisis organisasi. Itu adalah dinamis, menjembatani tingkat-tingkat dengan mekanisme spesifik. Itu melibatkan proses belajar yang berlipat (intuisi, mengintegrasikan, menafsirkan, dan melembagakan) yang memungkinkan pembelajar memberi umpan kepada level organisasi dan umpan balik kepada individu. Banyak organisasi pembelajar yang sukses menyusun keunggulan mereka dengan mendorong karyawan pada semua level untuk mengumpulkan dan membagikan informasi lintas batas dari pada menyimpannya. Ini difasilitasi melalui komunikasi dan informasi yang membuat sharing pengetahuan sebuah jalan hidup. Pada akhirnya, satu dari banyak kualitas penting bagi sebuah organisasi pembelajar memiliki budaya yang kuat yang mendukung tidak hanya penciptaan pengetahuan tetapi transfer lintas batas divisi dan fungsi. Dalam sebuah studi yang menguji kegunaan pengetahuan bagi inovasi teknologi dalam perusahaan yang beragam, temuannya mengungkapkan bahwa kegunaaan dari pengetahuan antar divisi atas dampak penemuan yang kuat dari pada pengaruh penggunaan pengetahuan dari dalam batas divisi sendiri.

5. Organisasi pembelajar mencakup gagasan bahwa orang akan belajar jika didorong untuk menghadapi tantangan, eksperimen, kegagalan, dan bercermin pada pengalamannya ${ }^{15}$.

Beberapa contoh organisasi pembelajar hari ini termasuk: Microsoft, Toyota, W.L. Gore \& Associates, Xerox, 3M, Johnson \& Johnson, Procter \& Gamble, dan perusahaan berbasis internet seperti: Google dan eBay. Perusahan-perusahaan ini menemukan bahwa sukses adalah lebih tentang pemeliharaan imajinasi, kreatifitas, dan

15 Achua, C. F., \& Lussier, R. N. (2013). Effective leadership. SouthWestern Cengage Learning. 
keinginan besar karyawan untuk menyelesaikan masalah-masalah pelanggan dari pada fokus pada biaya dan keuntungan ${ }^{16}$.

\section{Perolehan Pengetahuan dan Pembelajaran VS Kinerja Perusahaan}

Para peneliti menemukan bahwa tingginya tingkat perolehan pengetahuan dan pembelajaran, besarnya tingkat kinerja perusahaan. Dari sebuah level kecil standpoint, studi yang memiliki fokus berbeda pada hubungan antara perolehan pengetahuan dan indicator kinerja spesifik:

1. Studi yang menyelidiki hubungan antara penciptaan pengetahuan dan penciptaan nilai menemukan bahwa kemampuan perusahaan menciptakan dan membagikan pengetahuan berhubungan secara positif terhadap keberhasilan pengembangan produk baru.

2. Temuan dari beberapa studi mendukung proposisi bahwa pembelajaran organisasi dan penciptaan pengetahuan memiliki pengaruh positif langsung terhadap tingkat inovasi.

3. Budaya organisasi pembelajar memiliki dampak langsung positif pada tingkat kepuasan karyawan, pelanggan, dan pemasok.

4. Perolehan pengetahuan eksternal memiliki dampak positif atas proses kreatifitas dan pembelajaran problem solving ${ }^{17}$.

\section{Peran Pemimpin dalam Organisasi Pembelajar}

Peran pemimpin adalah kunci dalam membantu mengembangkan budaya pembelajar ${ }^{18}$. Banyak studi dan ahli setuju bahwa manajemen pengetahuan adalah kunci fungsi pemimpin. Pengetahuan telah diidentifikasi sebagai satu dari banyak sumber daya penting yang berkontribusi kepada keunggulan bersaing organisasi. Kinerja tinggi yang dicapai ketika memperoleh pengetahuan baru

16 Achua, C. F., \& Lussier, R. N. (2013). Effective leadership. SouthWestern Cengage Learning. Liha juga Maulana, A. (2015).

17 Achua, C. F., \& Lussier, R. N. (2013). Effective leadership. SouthWestern Cengage Learning. Bandingkan dengan Ciptagustina, A. (2014). Pengaruh Manajemen Pengetahuan Melalui Knowledge Worker Terhadap Efektivitas Organisasi Program Studi S1 Di Universitas Pendidikan Indonesia. Image: Jurnal Riset Manajemen, 3(1).

18 Ambarwati, S. D. A. (2003). Mengelola perubahan organisasional: Isu peran kepemimpinan transformasional dan organisasi pembelajaran dalam konteks perubahan. Jurnal Fakultas Hukum UII, 2(8). 
diinterpretasikan dan diintegrasikan dengan pengetahuan yang ada dan diterapkan kepada penyelesaian masalah.

Kegagalan dalam usaha menciptakan budaya pembelajar sering dianggap sebagai gejala kepemimpinan yang miskin. Untuk sukses dalam ekonomi berbasis pengetahuan, pemimpin ditantang untuk melakukan transformasi organisasi kedalam kecakapan system yang fleksibel tentang adaptasi besar dan pembelajaran terusmenerus ${ }^{19}$. Membersihkan rintangan terhadap sharing informasi, seperti keengganan beberapa anggota untuk berbagi informasi, meningkatkan tidak hanya proses pembelajaran tetapi juga pertukaran dan penciptaan pengetahuan ${ }^{20}$. Pemimpin dalam organisasi pembelajar menghadapi tantangan ganda untuk memelihara operasi yang efisien dan menciptakan organisasi yang adaptif pada waktu yang sama. Teridentifikasi bahwa inisiatif kepemimpinan penting untuk mempertinggi pembelajaran dan memimpin pada pengetahuan baru. Berikut pedoman cara dalam mana seorang pemimpin dapat menciptakan kondisi yang kondusif untuk pembelajaran dan penciptaan pengetahuan.

Peragaan 2. Pedoman Pembelajaran Organisasi ${ }^{21}$.

- Mendorong pemikiran kreatif

- Menciptakan iklim mendorong eksperimentasi

- Memberikan insentif bagi pembelajaran dan inovasi

- Membangun kepercayaan dalam kapasitas pengikut untuk belajar dan beradaptasi

- Mendorong pemikiran system

- Menciptakan budaya yang kondusif untuk pembelajaran tim dan individual

- Melembagakan mekanisme untuk menyalurkan dan memelihara ide-ide kreatif untuk inovasi

${ }^{19}$ Salah satu ciri kualitas adalah perbaikan berkelanjutan. Dalam organisasi pembelajar, riset menjadi alat ampuh untuk melakukan perbaikan secara terus menerus. Lihat Syahrul, S. (2013). Penelitian sebagai Instrumen Perbaikan Kualitas Kinerja Organisasi Pendidikan secara Berkelanjutan (Continuous Improvement). AlTa'dib, 6(1), 150-163.

${ }^{20}$ Nasution, M. K. (2013). Teknologi pengetahuan. Dies Fasilkom-TI USU.

21 Achua, C. F., \& Lussier, R. N. (2013). Effective leadership. SouthWestern Cengage Learning. Liha juga Maulana, A. (2015). 
- Menciptakan visi bersama untuk pembelajaran

- Memperluas kerangka acuan karyawan

- Menciptakan lingkungan yang mana orang dapat belajar dari kesalahan

\section{Mendorong Pemikiran Kreatif}

Meskipun kapasitas sebuah organisasi untuk menjadi lebih kreatif harus dimulai pada tingkat individual, kreatifitas pada tingkat organisasi juga penting ${ }^{22}$. Pada level organisasi, kreatifitas dipengaruhi oleh tipe gaya kepemimpinan, budaya, iklim, struktur, dan system yang dimiliki organisasi tersebut. Juga, sumberdaya dan keahlian yang dimiliki organisasi yang akan memainkan peran tersebut. Factor-faktor organisasi ini lebih lanjut diuji sebagai bagian dari diskusi atas pedoman untuk meningkatkan pembelajaran organisasi.

Pada tingkat individu, pemimpin yang dapat mempertinggi pembelajaran dengan mendorong anggota untuk "berpikir di luar kotak"- dalam kata lain, mempertimbangkan kemungkinankemungkinan yang belum terjadi. Dari pada merespon untuk mengetahui tantangan, karyawan didorong untuk menciptakan masa depan. Ini adalah budaya yang mendorong inovasi. Orang dengan gagasan yang hebat atau luar biasa harus disambut dan diberikan ruang untuk berbuat dalam sebuah organisasi pembelajar. Orang yang menganjurkan radikal atau berbeda ide tidak harus dilihat sebagai sesuatu yang mengganggu dan menyulitkan.

Pendekatan untuk meningkatkan pemikiran kreatif adalah mendorong karyawan untuk meneliti dan belajar dari beberapa pesaing terbaik dalam industry. Proses ini, dikenal sebagai benchmarking, yang memungkinkan sebuah perusahaan meniru praktek terbaik dari yang lain ${ }^{23}$. Akan tetapi, meniru belaka bukanlah hasil dari sebuah keunggulan bersaing; itu adalah pengikut strategi. Sebuah organisasi harus memperbaiki praktek terbaik pesaing dan meluncurkan inovasi di depan para pesaing.

${ }^{22}$ Purhantara, W. (2012). Menciptakan organisasi yang kreatif. Jurnal Economia, 8(2), 153-163.

${ }^{23}$ Pawitra, T. (1994). Patok Duga (Benchmarking): Kiat Belajar Dari yang Terbaik. Manajemen and Usahawan Indonesia, 23(1). 


\section{Menciptakan Iklim Yang Mendorong Eksperimentasi}

Pembelajaran adalah lebih mungkin untuk mengambil tempat dalam organisasi yang mana eksperimentasi dalam skala kecil didorong dan diperbolehkan. Tujuan dari eksperimen adalah untuk belajar dari kesalahan dalam sebuah lingkungan yang terkontrol. Biaya kegagalan tidak sepenting dalam upaya nyata. Orang yang takut pada kegagalan dan resiko, reputasi dan karir mereka lebih mungkin mencoba sesuatu yang baru atau kreatif dalam skala kecil. Pemimpin juga harus menciptakan budaya yang memelihara dan bahkan merayakan eksperimentasi dan inovasi. Setiap orang harus diharapkan menyumbang ide-ide, menunjukkan inisiatif, dan mengejar perbaikan terus-menerus. Salah satu cara untuk melakukan hal itu adalah menciptakan rasa urgensi dalam organisasi, sehingga orang melihat perubahan dan inovasi sebagai sebuah kebutuhan. Cara lainnya adalah kadangkala memberikan reward kepada orang-orang yang gagal, karena itu adalah simbolisasi pentingnya pengambilan resiko ${ }^{24}$.

\section{Memberikan Insentif bagi Pembelajaran dan Inovasi}

Penggunaan insentif dan reward adalah sebuah alat kuat yang dapat pemimpin lakukan untuk mendorong pembelajaran dan inovasi. Organisasi sering dikritik memproklamirkan diri mereka sendiri sebagai juara pembelajaran tetapi tidak dapat memberi pekerja jenis nyata dukungan yang dibutuhkan untuk memotivasi mereka. Reward bagi ide-ide dan inovasi yang berhasil harus besar dan terlihat oleh orang lain untuk memperhatikan. Reward dan insentif menguatkan pembelajaran dan inovasi positif dalam organisasi. Pimpinan harus mengambil langkah untuk mendorong dan mendukung pembelajaran dan inovasi di tempat kerja ${ }^{25}$.

\section{Membangun Kepercayaan dalam Kapasitas Pengikut untuk Belajar dan Beradaptasi}

Lingkungan organisasi pembelajar adalah salah satu perubahan cepat, dimana keberlangsungan hidup tergantung pada repons yang tepat waktu terhadap tantangan dan peluang. Memberikan peluang bagi karyawan untuk memecahkan masalah kelompok ataupun unit akan meningkatkan kebanggaan dan kepercayaan diri mereka dalam

\footnotetext{
${ }^{24}$ Suryana, A. (2010). Kepemimpinan Pendidikan.

${ }^{25}$ MUNDIR, A. (2016). Pemimpin Profesional Madrasah. Fikrotuna, 4(2).
} 
proses. Dengan setiap kesuksesan yang dirayakan mendatangkan kepercayaan yang lebih besar dalam menangani perubahan. Dari waktu ke waktu, keakraban dengan proses perubahan akan menciptakan sebuah apresiasi bagi flexibilitas dan pembelajaran ${ }^{26}$.

\section{Mendorong Pemikiran Sistem}

Untuk meningkatkan pembelajaran, pemimpin seharusnya membantu anggota menganggap organisasi sebagai sebuah system dimana setiap pekerjaan orang mempengaruhi karya orang lain. Setiap orang dalam organisasi mempertimbangkan bagaimana tindakan mereka mempengaruhi elemen-eleman lain organisasi. Penekanan pada seluruh system menurunkan batas-batas dalam organisasi dan dengan perusahaan-perusahaan lain, yang memungkinkan bagi kolaborasi dan pembelajaran terus-menerus. Anggota mulai melihat bagaimana hubungan dengan perusahaan lainnya dapat menurunkan biaya, meningkatkan penjualan, ataupun membawa dalam kompetensi-kompetensi baru ${ }^{27}$.

\section{Menciptakan Budaya yang Kondusif untuk Pembelajaran}

\section{Tim dan Individual}

Pengembangan pribadi dan pembelajaran seumur hidup harus dikuatkan oleh nilai budaya dalam organisasi pembelajar. Pemimpin harus menciptakan budaya, yang mana setiap orang dinilai, dan organisasi mempromosikan dan mendukung pengembangan potensi mereka sepenuhnya. Tipe budaya pembelajaran ini mendorong kegiatan inisiatif diri, serendipity, dan komunikasi dalam perusahaan. Dalam tipe budaya pembelajar ini, kepemimpinan menawarkan dukungan total, karyawan mengambil kepemilikan pekerjaan mereka, dan fungsi manajer lebih sebagai fasilitator dan pemberi tugas. Aspek lain dari penciptaan sebuah budaya yang kondusif untuk pembelajaran adalah konsep keragaman tim. Pemimpin harus menjamin bahwa keragaman ada dalam tim mereka. Penelitian telah menemukan bahwa tim yang beragam dapat meningkatkan pembelajaran karena

\footnotetext{
${ }^{26}$ Haryati, E. (2014). Pengaruh Persepsi Kepemimpinan Transformasional dan Budaya Organisasi Terhadap Organizational Citizenship Behaviour Pada Pegawai Politeknik LP3i Medan (Doctoral dissertation, Universitas Medan Area).

27 Maguni, W. (2014). Manajemen Organisasi Pembelajaran dan Kepemimpinan. Al-Ta'dib, 7(1), 131-148.
} 
anggota dari wilayah keahlian yang berbeda dikombinasikan untuk menghasilkan pengetahuan dan wawasan baru ${ }^{28}$.

Melembagakan mekanisme untuk menyalurkan dan memelihara ide-ide kreatif untuk inovasi

Lahirnya ide-ide dan pengetahuan baru dimulai dari individu. Membuat ketersediaan pengetahuan pribadi terhadap yang lain adalah kegiatan sentral dari penciptaan pengetahuan organisasi. Pengetahuan yang dibagi dapat membantu karyawan dalam masalah-masalah yang sulit ataupun memberikan peluang bagi karyawan dari bagian organisasi yang berbeda untuk berinteraksi satu sama lain, mendapatkan nasihat dan memberikan dukungan tentang masalahmasalah bersama. Ide-ide yang dihasilkan di dalam maupun di luar organisasi dapat menjadi sumber dari produk dan inovasi baru. Tim venture, gugus tugas, jaringan system informasi, seminar-seminar, dan workshop dapat digunakan untuk pembauran pengetahuan dan penyaluran ide-ide kreatif pada tempat yang tepat bagi evaluasi dan aplikasi. Proses ini dilembagakan, pertukaran dan penciptaan pengetahuan menjadi bagian dari budaya ${ }^{29}$.

\section{Menciptakan Visi Bersama bagi Pembelajaran}

Menciptakan sebuah visi bersama dapat meningkatkan pembelajaran sebagai anggota organisasi, mengembangkan tujuan dan komitmen bersama untuk membuat pembelajaran an ongoing bagian dari organisasi. Jika karyawan semuanya percaya bahwa organisasi menuju kebesaran, mereka akan termotivasi menjadi bagian dari itu melalui pembelajaran dan persembahan solusi dan ide-ide terbaik mereka $^{30}$.

${ }^{28}$ Wibowo, A., \& Saptono, A. (2017). Kepemimpinan Intrapreneurship, Budaya Sekolah dan Kinerja Inovasi Guru. Jurnal Pendidikan Ekonomi Dan Bisnis (JPEB), 5(2), 176-193.

29 Syahrul, S. (2015). Kepemimpinan dan Inovasi Lembaga Pendidikan (Pengalaman Pondok Gontor VII Putra Sulawesi Tenggara). Al-Ta'dib, 8(1), 82-100.

${ }^{30}$ Sugiyarti, G. (2015). Membangun Keunggulan Bersaing Produk Melalui Orientasi Pembelajaran, Orientasi Pasar Dan Inovasi Produk (Studi Empiris Pada Industry Pakaian Jadi Skala Kecil Dan Menengah Di Kota Semarang). Serat Acitya, 4(2), 110. 


\section{Memperluas kerangka acuan karyawan}

Kerangka acuan seseorang menentukan bagaimana mereka melihat dunia. Cara yang kami kumpulkan, analisis, dan interpretasi infornasi -dan bagaimana kami mengambil keputusan berbasis informasi- dipengaruhi oleh kerangka acuan personal kita. Kerangka acuan menentukan apa asumsi-asumsi tersirat yang seseorang pegang, dan asumsi-sumsi itu, sadar atau tidak sadar, mempengaruhi bagaimana mereka menafsirkan peristiwa. Untuk meningkatkan kemampuan belajar karyawan, hal itu bermanfaat bagi pemimpin untuk memperluas kerangka-kerangka yang digunakan karyawan untuk melihat organisasi dan lingkungan eksternalnya. Pembelajaran dipaksa ketika pemimpin dan pengikutnya gagal melihat dunia dari perspektif yang berbeda dan tidak membantu organisasi beradaptasi terhadap lingkungan yang berubah. Perluasan kerangka acuan karyawan ataupun perspektif menyediakan berbagai pendekatan yang lebih besar untuk menyelesaikan masalah dan kemudian memudahkan pembelajaran dan perbaikan berkelanjutan ${ }^{31}$.

\section{Menciptakan lingkungan belajar}

Beberapa dari banyak penemuan penting ataupun terobosan ilmiah dihasilkan dari penyelidikan yang hasilnya gagal. Sayangnya, di banyak organisasi, ketika eksperimen atau usaha skala penuh gagal, kecenderungannya adalah meninggalkan aktifitas dengan segera untuk menyelamatkan mudan ataupun menghindari konsekwensikonsekwensi negatif. Ini adalah pendekatan yang salah, karena banyak pembelajaran mengambil tempat dari sesuatu yang salah ketimbang dari sesuatu yang benar. Setelah semuanya, ketika hal-hal berubah sebagaimana yang diharapkan, hal itu hanyalah konfirmasi teori dan asumsi-asumsi yang ada. Penglihatan baru lebih mungkin ketika ada penyelitian tentang "mengapa hasil yang diharapkan tidak terealisasi". Sehingga, untuk mendorong pembelajaran, pemimpin harus mengkomunikasikan pandangan bahwa kegagalan (dapat) ditoleransi. Kemudian, mereka harus menyediakan peluang kepada orang untuk ikut serta dalam review pasca kegiatan terlepas dari apapun hasilnya ${ }^{32}$.

${ }^{31}$ Muljani, N. (2004). Kompensasi sebagai motivator untuk meningkatkan kinerja karyawan. Jurnal Manajemen dan Kewirausahaan, 4(2), 108-122.

${ }^{32}$ Purwanto, A. J. (2007). Kajian Learning Organization pada Organisasi Publik. Jurnal Organisasi dan Manajemen, 3(1), 1-9. 
Menciptakan budaya yang menghargai orang-orang yang berhasil, maupun kadang penghargaan pada orang yang gagal, mengirim pesan bahwa organisasi mendorong pengambilan resiko. Menciptakan budaya dan lingkungan resiko yang kuat adalah tanggung jawab kepemimpinan yang tidak dapat diambi begitu saja. Organisasi dengan budaya sensitif resiko tercatat pada level tanggung jawab yang tinggi, penguatan, komunikasi, dengan manajemen resiko yang tepat dan sumber daya infrastruktur di tempat.

Pembelajaran adalah latihan yang tak pernah berakhir. Pemimpin harus mengkomunikasikan pesan bahwa pembelajaran dan perbaikan berkelanjutan adalah permintaan lingkungan bisnis dinamis yang tinggi hari ini. Pemimpin harus memimpin dalam menantang status quo dan menciptakan kondisi organisasi yang kondusif untuk belajar dan inovasi berkelanjutan.

\section{Kesimpulan}

Diskursus organisasi pembelajar hadir bersamaan dengan ledakan teknologi informasi dan komunikasi yang memengaruhi kehidupan manusia secara signifikan. Organisasi tidak ada yang mau disebut tradisional baik secara formal maupun substantif, sehingga harus mengikuti hukum perubahan tersebut. Manfaat organisasi pembelajar yang telah dirasakan oleh organisasi-organisasi nirlaba memantik organisasi non profit untuk mengadopsi konsep organisasi pembelajar. Pengelolaan pengetahuan adalah karakteristik utama dalam organisasi pembelajar. Tipikal organisasi yang senantiasa belajar, menguasai dan memanfaatkan pengetahuan untuk keunggulan organisasi. 


\section{Daftar Pustaka}

Achua, C. F., \& Lussier, R. N. (2013). Effective leadership. SouthWestern Cengage Learning.

Ambarwati, S. D. A. (2003). Mengelola perubahan organisasional: Isu peran kepemimpinan transformasional dan organisasi pembelajaran dalam konteks perubahan. Jurnal Fakultas Hukum UII, 2(8).

Ciptagustina, A. (2014). Pengaruh Manajemen Pengetahuan Melalui Knowledge Worker Terhadap Efektivitas Organisasi Program Studi S1 Di Universitas Pendidikan Indonesia. Image: Jurnal Riset Manajemen, 3(1).

Haryati, E. (2014). Pengaruh Persepsi Kepemimpinan Transformasional dan Budaya Organisasi Terhadap Organizational Citizenship Behaviour Pada Pegawai Politeknik LP3i Medan (Doctoral dissertation, Universitas Medan Area).

Ismail, D. H. (2017). Strategi Mewujudkan Suatu Organisasi Pembelajar. Jurnal Lentera Bisnis, 5(1), 9-30.

Lisdiantini, N. (2013). Pengaruh Budaya Organisasi dan Kepemimpinan Kewirausahaan terhadap Motivasi Karyawan dan Dampaknya pada Peningkatan Kinerja Organisasi (Studi Pada PT Industri Kereta Api/INKA Madiun). Widya Warta, 37(02).

Maguni, W. (2014). Manajemen Organisasi Pembelajaran dan Kepemimpinan. Al-Ta'dib, 7(1), 131-148.

Manullang, M. (2013). Pengaruh Pengetahuan Organisasi, Motivasi Berprestasi, Pengambilan Keputusan, Dan Komitmen Organisasi Terhadap Kinerja Kepala Sekolah Studi Pada Smp Kota Medan (Doctoral dissertation, UNIMED).

Marlikan, M. (2013). Pengaruh Pembelajaran Organisasi dan Motivasi kerja terhadap Kinerja Karyawan Koperasi Syariah. Manajemen Bisnis, 1(1), 57-64.

Maulana, A. (2015). Manajemen Strategik

Muljani, N. (2004). Kompensasi sebagai motivator untuk meningkatkan kinerja karyawan. Jurnal Manajemen dan Kewirausahaan, 4(2), 108-122.

Munir, N. S. (2011). Penerapan Manajemen Pengetahuan di Perusahaan di Indonesia. PPM Manajemen. 
Mundir, A. (2016). Pemimpin Profesional Madrasah. Fikrotuna, 4(2).

Nasution, M. K. (2013). Teknologi pengetahuan. Dies Fasilkom-TI USU.

Pawitra, T. (1994). Patok Duga (Benchmarking): Kiat Belajar Dari yang Terbaik. Manajemen and Usahawan Indonesia, 23(1).

Purhantara, W. (2012). Menciptakan organisasi yang kreatif. Jurnal Economia, 8(2), 153-163.

Purwanto, A. J. (2007). Kajian Learning Organization pada Organisasi Publik. Jurnal Organisasi dan Manajemen, 3(1), 1-9.

Raharso, S., \& Amalia, S. (2011). Tim dan organisasi pembelajar. Jurnal Administrasi Bisnis, 7(2).

Sugiyarti, G. (2015). Membangun Keunggulan Bersaing Produk Melalui Orientasi Pembelajaran, Orientasi Pasar Dan Inovasi Produk (Studi Empiris Pada Industry Pakaian Jadi Skala Kecil Dan Menengah Di Kota Semarang). Serat Acitya, 4(2), 110.

Suryana, A. (2010). Kepemimpinan Pendidikan.

Syahrul, S. (2013). Penelitian sebagai Instrumen Perbaikan Kualitas Kinerja Organisasi Pendidikan secara Berkelanjutan (Continuous Improvement). Al-Ta'dib, 6(1), 150-163.

Syahrul, S. (2016). Readines Frame: Analisis Kerangka Kesiapan dalam Transformasi Pendidikan Tinggi (Pengalaman Iain Kendari). Al-Ta'dib, 9(1), 162-181.

Syahrul, S. (2017). Perencanaan Strategis dan Praktiknya di Perguruan Tinggi. Shautut Tarbiyah, 23(1), 142-159.

Syahrul, S. (2015). Kepemimpinan dan Inovasi Lembaga Pendidikan (Pengalaman Pondok Gontor VII Putra Sulawesi Tenggara). Al-Ta'dib, 8(1), 82-100.

Tjahjadi, B. (2011). Hubungan sistem manajemen risiko dengan ketidakpastian lingkungan dan strategi serta dampaknya terhadap kinerja organisasi. Jurnal Ekonomi dan Bisnis Airlangga (JEBA)| Journal of Economics and Business Airlangga, 21(2).

Trang, D. S. (2013). Gaya kepemimpinan dan budaya organisasi pengaruhnya terhadap kinerja karyawan. Jurnal EMBA: Jurnal Riset Ekonomi, Manajemen, Bisnis Dan Akuntansi, 1(3).

Wardani, A. K. (2018). Dormansi Organisasi Di Era Globalisasi. Moderat: Jurnal Ilmiah Ilmu Pemerintahan, 4(3), 28-35 